\title{
@mniaScience
}

\section{Marketing assets: Relating brand equity and customer equity}

\author{
Jaime Romero (iD, María J. Yagüe (iD \\ Universidad Autónoma de Madrid (Spain) \\ jaime.romero@uam.es,maria.yague@uam.es
}

Received October, 2015

Accepted January, 2016

\section{Abstract}

Purpose: Brand equity and customer equity are inextricably linked. Some authors propose that marketing activities build these intangible assets simultaneously. In contrast, others suggest that brand equity is an antecedent of customer equity. In this research, we aim to shed light about the relationship between brand equity and customer equity, by empirically testing these two alternative explanations.

Design/methodology: We propose four research models that reflect these two alternatives explanations regarding the link between brand equity and customer equity. In order to estimate these models we employ Structural Equations Modelling. We measure model variables using data collected through a survey to marketing managers of services companies that operate in Spain. We compare these four research models in terms of explanatory power and goodness of fit.

Findings: Our results indicate that the models that correspond to the simultaneity approach have a higher explanatory power and goodness of fit than the models that suggest that brand equity is an antecedent of customer equity, thus supporting that these intangible assets are built by marketing activities at the same time. 
Research limitations/implications: Our results recommend caution when interpreting previous research about the effects of brand (customer) equity, as they might indeed correspond to customer (brand) management. Similarly, future research focusing on customer and brand management need to take into account both managerial areas in their studies.

Practical implications: From a practitioners' point of view, our findings suggest adopting a brand-customer portfolio approach to enhance company profitability. Similarly, we derive implications for firm valuation processes, which incorporate brand equity and customer equity in their calculations.

Originality/value: We empirically study the relationship between brand equity and customer equity, while previous research has analyzed this topic only at a theoretical level. Clarifying this link enriches our comprehension about how companies build these marketing intangible assets and increases the accuracy of firm valuation processes.

Keywords: Brand equity, Customer equity

Jel Codes: M31

\section{Introduction}

Brand and customer portfolios are intangible marketing assets that help companies to make profits because of their effect upon competitive advantages. Academic literature has studied how to manage (build and develop) and measure the value - Brand Equity (hereafter, BE) and Customer Equity (CE) - that these assets provide to companies. In short, BE is the differential effect of brand knowledge (including brand image and brand awareness) on consumer response to the elements of marketing mix for the brand in comparison to the same elements of a fictitiously named or unnamed version of the product or service (Keller, 1993, 2008). In contrast, CE has a purely financial nature, as is the discounted stream of expected profits from the actual and potential customers of a firm (Rust, Lemon \& Zeithaml, 2004). In this research we use the terms BE and CE to describe the assets built by marketing activities focused on brands and customers, respectively, and that are expected to provide future cash flows to a company (Hogan, Lemon \& Rust, 2002; Yoo, Donthu \& Lee, 2000; Villanueva, Yoo \& Hanssens, 2008). 
Research efforts involving BE and CE have generally constituted well-differentiated lines of research. On the one hand, BE studies spread in the early 1990s and tend to concentrate on its conceptualization and measurement (Aaker, 1991; Keller, 1993; Netemeyer, Krishnan, Pullig, Wang, Yagci, Dean, Ricks \& Wirth, 2004; Wang, Hsu \& Fang, 2009; Christodoulides \& de Chernatony, 2010). On the other hand, the concept of $\mathrm{CE}$ has become popular over the past ten years and its research focuses on its measurement and optimization (e.g.: Berger \& Nasr, 1998; Allenby, Leone \& Jen, 1999; Gupta, Lehmann \& Stuart, 2004; Venkatesan \& Kumar, 2004; Fader, Hardie \& Lee 2005a, 2005b; Wiesel, Skiera \& Villanueva, 2008).

Hence, there is some parallel development of the research into BE and CE, and these concepts are intimately related (Leone, Rao, Keller, Luo, Mcalister \& Srivastava, 2006; Spyropoulou, Skarmeas \& Katsikeas, 2011; Luo, Lehmann \& Neslin, 2015). Building BE modifies customer choices and brand sales, producing cash flows from the customer to the company (Srivastava, Shervani \& Fahey, 1998; Kim, Kim Woo \& An Jeong, 2003; Rao, Agarwal \& Dahlhoff, 2004; Johansson, Dimofte \& Mazvancheryl, 2012), in short BE. Similarly, CE increases BE through several ways, "including: social influence, market presence, customer satisfaction, advocacy and network externalities" (Luo et al., 2015). Furthermore, building BE and CE requires having the similar marketing capabilities (marketing capabilities understood as the ability of a firm to efficiently deploy and manage its marketing resources; Porter, 1985, 1991). Both BE and CE are related with specific outputs - competitive advantages, namely customers' loyalty and their willingness to pay price premiums (Lassar, Mittal \& Sharma, 1995; Taylor, Celuch \& Goodwin, 2004; Del Río, Vázquez \& Iglesias, 2001; Faircloth, Capella \& Alford, 2001; Alawadi, Lehmann, and Neslin 2003; Kim \& Kim Woo, 2005; Rust, Lemon et al., 2004).

Despite these coincidences, there are seldom studies about the potential links between BE and CE (Villanueva \& Hanssens 2007). The few studies to date of the connection between BE and CE adopt two different perspectives. On the one hand, some authors posit that the management of brands and customers could have some similar effects (Ambler, Bhattacharya, Edell, Keller, Lemon \& Mittal, 2002; Leone et al., 2006) and that there may be synergies in brand and customer management (Luo et al., 2015). These (theoretical) studies do not provide any empirical support for their conclusions. According to the authors that follow this perspective, BE and CE could occur simultaneously or even be two sides of the same asset (i.e., could be overlapping assets). Romero and Yagüe (2015) show that marketing managers indeed support this view, although still manage brands and customers somehow independently. On the other hand, Rust, Lemon et al. (2004) suggest that BE is an antecedent of CE, given that brands affect customers' choices across time and, therefore, the stream of profits provided 
by these customers during their lifetimes. More specifically, BE influences acquisition and retention rates and profit margins, which are three key components of CE (Stahl, Heitmann, Lehmann \& Neslin, 2012). Under this perspective, brand management is a tool for customer management.

These two conflicting points of view have important theoretical and practical implications. Clarifying if $\mathrm{BE}$ and $\mathrm{CE}$ are assets that either are built simultaneously or an antecedent and its consequence constitutes, for instance, a strong base for linking the separated research streams on BE and CE. Similarly, research about marketing profitability formation - an important topic that is generating a growing interest among academics and practitioners (Rust, Ambler, Carpenter, Kumar \& Srivastava, 2004) - requires accurately identifying how marketing activities (brand management and customer management) contribute through customers' loyalty or margins to company returns and, ultimately, to firm value. From a practitioners point of point of view, understanding the bond between $\mathrm{BE}$ and $\mathrm{CE}$ has a direct application in terms of marketing decisions aiming to enhance the long-term value of a company (Kumar, Lemon \& Parasuraman, 2006). The assessment of firm value also requires a complete comprehension of the connection between $\mathrm{BE}$ and $\mathrm{CE}$, given that both are intangible assets that affect firm valuation. Nevertheless, despite its theoretical and practical implications, up to our knowledge there are not studies that directly compare both views in the same research. The link between $\mathrm{BE}$ and $\mathrm{CE}$ remains obscure.

In this research we fill this gap by proposing four alternative research models that follow the two competing perspectives regarding the connection between $\mathrm{BE}$ and $\mathrm{CE}$. We depart from the resourcebased view theory to propose these models. They posit that marketing capabilities produce marketing assets (BE and $\mathrm{CE}$ ); and that such marketing assets provide competitive advantages (customers' loyalty and price premiums) to companies. We validate these models using survey data from a sample of marketing managers, grounding our findings on managerial practice. We examine our estimation results in the light of the competing perspectives and compare them in terms of their explanatory power and goodness of fit. Thus, we contribute to current knowledge about the connection between BE and CE by empirically testing the existing alternative explanations of such link.

Our findings indicate that $\mathrm{BE}$ and $\mathrm{CE}$ are intangibles assets that are built simultaneously by companies, against previous evidences that assume that $\mathrm{BE}$ is an antecedent of $\mathrm{CE}$ (e.g.: Chen \& Myagmarsuren, 2011; Hao, Ko \& Tailor, 2010; Allaway, Huddleston, Whipple \& Ellinger, 2011; Ramaseshan, Rabbanee \& Tan Hsin Hui, 2013). Moreover, our results indicate that BE and CE could just respond to different perspectives of the valuation of a more general and holistic marketing asset. From a theoretical point of view, our results recommend enriching $\mathrm{BE}$ and $\mathrm{CE}$ research streams by integrating them, avoiding its 
current separation. Marketing profitability research and management require adopting a joint perspective of these assets. The BE-CE connection is the key for building stronger brands and increasing the customer base of a firm (Kumar, Lemon \& Parasuraman, 2006; Luo et al., 2015) in order to ensure sustainable competitive advantages. According to our results a growth in $\mathrm{BE}$ and $\mathrm{CE}$ leads both to a greater customer willingness to pay premiums and to a higher loyalty among customers, respectively (and not indistinctly, as in previous studies). Finally, our results recommend moving to a brand-customer portfolio approach for managing marketing activities and a careful assessment of BE and $\mathrm{CE}$ when valuing firms, in order to avoid inflating firm value when taking into account both assets in firm valuation processes.

The remainder of this paper is organized as follows. In the second section we briefly introduce our theoretical framework, presenting a review of the relationship between BE and CE. Next, we formulate our research models. The third section provides details of the method followed for gathering and processing the information, and for measuring the latent variables included in the models via the development of scales. Subsequently, we analyze the results obtained from the estimation of the models in terms of goodness of fit and model relationships. Finally, we present our principal conclusions, and suggest future lines of research, aimed at overcoming some of the limitations of this work.

\section{Theoretical models}

\subsection{Marketing capabilities, assets and competitive advantage}

Research embedded in the resource-based view theory and its subsequent developments (the dynamic capabilities theories; Teece \& Pisano 1994; Teece, Pisano \& Shuen 1997), together with specific marketing literature (Srivastava, Shervani \& Fahey, 1999; Srivastava, Fahey \& Christensen, 2001), establishes that investing in marketing resources influences company profitability and firm value. Several studies have identified different types of marketing capabilities (Morgan, Slotegraaf \& Vorhies, 2009; den Hertog, van der Aa \& de Jong, 2010) that are useful for generating market-based assets (Srivastava et al., 1998) and competitive advantages (Srivastava et al., 2001). Consistent with these studies, our theoretical models to relate BE and CE share the following structure: marketing capabilities influence the creation of marketing assets; building these assets affords differentiation advantages to companies. More specifically, marketing capabilities generate $\mathrm{BE}$ and (at least indirectly) CE. By enhancing these assets, companies secure higher profits from the market via two mechanisms based on product differentiation. First, customers are willing to pay more for a product (Srivastava et al., 1998; 
Ailawadi, Lehmann \& Neslin, 2003). Second, a stable and sustained purchase level over time is more likely (Gupta \& Lehmann, 2003).

Traditionally, literature on the resource-based view has treated marketing capabilities as an aggregate (Vorhies \& Morgan, 2005) or as a concept consisting of two types of components: those associated with marketing mix capabilities and those of the strategic marketing process (Morgan, Vorhies \& Mason, 2009). Recently, some academics have grouped the former (that is, marketing mix capabilities) in accordance with the type of market-based assets they develop (Srivastava et al., 1998). Thus, marketing mix capabilities involve capabilities developed by the company in order to create and manage stronger and closer relations with its customers (Rust, Zeithaml \& Lemon, 2004), as well as others that are associated with the processes and activities that help the company to develop, support and maintain strong brands (Aaker, 1991; Hulland, Wade \& Antia, 2007).

Investing in brand capabilities constitutes an outstanding tool for improving the results of an organization (Keller, 1993; Kerin \& Sethuraman, 1998; Ambler, 2003; Raggio \& Leone, 2007). The greater the value of an organization's brands, the greater its competitive differentiation advantages (Aaker, 1991; Nurittamont \& Ussahawanitchakit, 2008; Lassar et al., 1995), the better the results it achieves (Aaker, 1991, 1996; Keller, 1993; Park \& Srinivasan, 1994; Nurittamont \& Ussahawanitchakit, 2008) and the higher its market value (Simon and Sullivan, 1993; Kerin \& Sethuraman, 1998). Studies in Customer Relationship Management and CE (Gupta et al., 2004; Rust, Lemon et al., 2004; Bauer \& Hammerschmidt, 2005) likewise conclude that companies that strengthen customer capabilities (by applying Customer Relationship Management techniques) improve their value via future profits generated by the accumulation of $\mathrm{CE}$.

Previous research associates $\mathrm{BE}$ and $\mathrm{CE}$ with two types of competitive advantages based on differentiation (in contrast to cost leadership; see Porter $(1980,1985))$. Namely, these competitive advantages are a greater predisposition to pay a price premium for the company goods and services and a higher customer loyalty. (In our study loyalty is a consequence and not a component of BE, consistent with previous research, e.g.: Taylor, Hunter \& Lindberg, 2007; Chen \& Myagmarsuren, 2011; Juntunen, Juntunen \& Juga, 2011; Geigenmüller \& Bettis-Outland, 2012). On the one hand, strong brands generate loyal customers who value these brands above all others in the market, who repurchase the brand on a regular basis, and who consider entirely reasonable to pay more for it (Aaker, 1991; Park \& Srinivasan, 1994; Taylor et al., 2007; Jobber \& Shipley, 2012). On the other hand, a high CE implies high retention rates and margins that ensure stable income flows in the future (Berger \& Nasr, 1998; Gupta \& Lehmann, 2003). In other words, in BE and CE literature, customer loyalty is therefore seen 
as a common benefit derived from the construction of these market assets. The price premium associated with $\mathrm{BE}$ and $\mathrm{CE}$ comes from an inelasticity in the demand of loyal customers (Rao \& Monroe, 1996).

In summary, previous research indicates that

- brand and customer capabilities increase BE and CE, and that

- $\mathrm{BE}$ and $\mathrm{CE}$ are positively related with gaining competitive advantages, namely customer loyalty and customer willingness to pay a premium price (Srivastava et al., 1998).

These findings are compatible with the competing explanations that researchers have proposed regarding the link between $\mathrm{BE}$ and $\mathrm{CE}$, which we explain next.

\subsection{Linking $\mathrm{BE}$ and $\mathrm{CE}$}

Given that $\mathrm{BE}$ and $\mathrm{CE}$ provide companies with present and future cash flows, it is reasonable to assume that BE and CE are highly correlated, if not equivalent (Ambler et al., 2002). However, some authors indicate that although built simultaneously there are relevant differences between them, representing specific contributions to company cash flows (Leone et al., 2006). For example, strong brands attract and retain not only consumers, but also more highly qualified employees; and they facilitate relations within distribution channels, presenting opportunities for growth via product line extensions, licenses and franchises (Jones, 2005; Chernatony, McDonald \& Wallace, 2010). In turn, customers can generate value for the company beyond their purchases by word-of-mouth or cocreation (van Doorn, Lemon, Mittal, Nass, Pick, Pirner \& Verhoef, 2010; Kumar, Aksoy, Donkers, Venkatesan, Wiesel \& Tillmanns, 2010). These effects and, therefore, the contribution of BE and CE to firm results might vary across industries (Bick, 2009), thus supporting the notion of BE as CE as separated assets.

Alternatively, some authors propose that BE is one of the antecedents of CE (Rust, Zeithaml \& Lemon, 2000; Rust, Lemon et al., 2004; Chen \& Myagmarsuren, 2011; Hao et al., 2010; Allaway et al., 2011; Holehonnur, Raymond, Hopkins \& Fine, 2009; Ramaseshan et al., 2013). Brands are, together with other CE antecedents (namely, value equity and relationship equity) a means of creating, developing and preserving profitable long-term relationships with customers. If the impact of other CE 
antecedents is strong, the correlation of $\mathrm{BE}$ and $\mathrm{CE}$ could be low. In line with this pers pective, Stahl et al. (2012) find that marketing activities grow CE not only through BE but also directly.

These two alternative explanations about the interdependence between $\mathrm{BE}$ and $\mathrm{CE}$ are compatible with the findings of studies that indicate that

- marketing capabilities increase BE and CE, and that

- $\mathrm{BE}$ and $\mathrm{CE}$ are positively related with customer loyalty and price premiums (Srivastava et al., 1998).

These studies do not incorporate simultaneously BE and CE and, therefore, the effect of marketing capabilities on them and their effects on competitive advantages could have been confounded (wrongly attributed, due to a potential correlation between $\mathrm{BE}$ and $\mathrm{CE}$, arising from their simultaneity or from $\mathrm{BE}$ being an antecedent of $\mathrm{CE}$ ).

Thus, in this study we propose two research models that

- reflect the two perspectives regarding the link between $\mathrm{BE}$ and $\mathrm{CE}$ and

- shed light about previous results about the role of marketing capabilities on BE and CE and the impact of these assets on loyalty and price premiums.

Our first research model (Figure 1a) establishes that BE and CE are two different views of the same marketing asset (Ambler et al., 2002). In this model, marketing capabilities positively influence a more general marketing asset, which increases loyalty and price premiums, (Srivastava et al., 1998; Srivastava et al., 2001). Following this view, we measure the marketing asset of our first model as a second order construct that is reflected by $\mathrm{BE}$ and CE. Assuming that this research model is true, the results of previous studies that include either BE or CE and find that they influence loyalty and price premiums could be due to the fact that these studies are indeed capturing the impact of a more general marketing asset (measured just either through BE or through CE).

In our second research model we set BE and CE separated (Bick, 2009; Leone et al., 2006), although correlated (Figure 1b). Both BE and CE influence loyalty and price premiums, as demonstrated by previous research. If this model is true, by separating the effects of $\mathrm{BE}$ and $\mathrm{CE}$ on loyalty and price premiums we can test whether these effects have been wrongly validated by previous research due the correlation between $\mathrm{BE}$ and $\mathrm{CE}$. 
(a) Model 1: One marketing asset

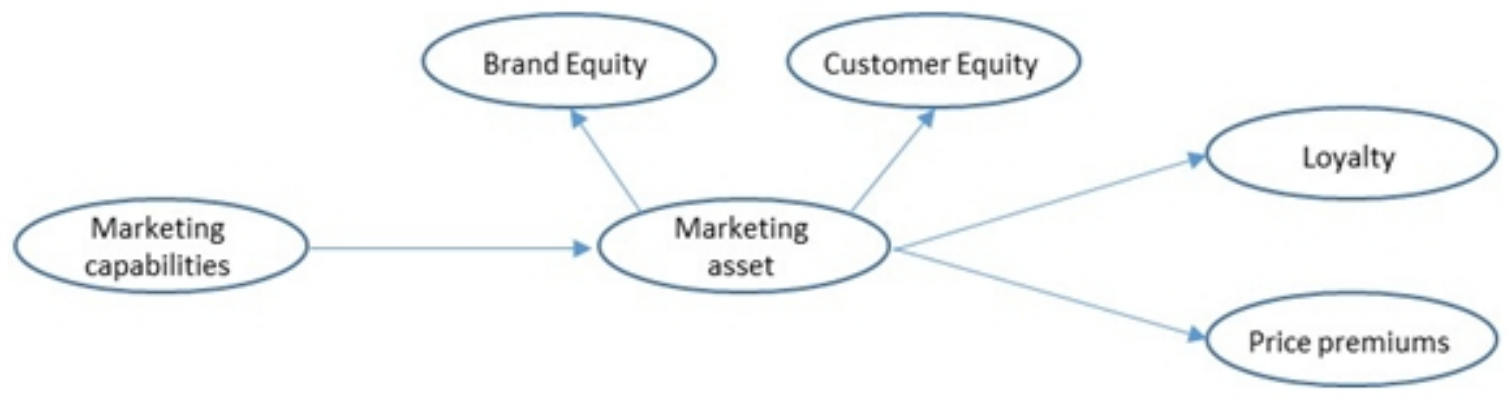

(b) Model 2: Two simultaneous marketing assets

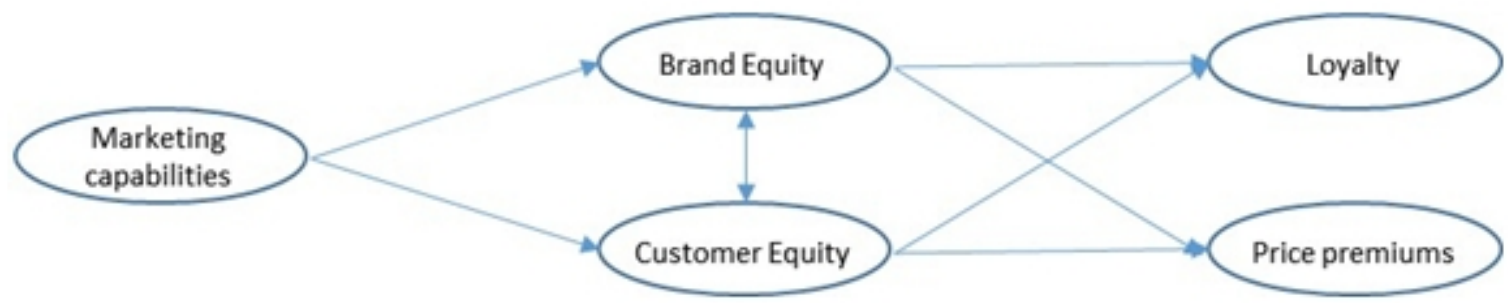

(c) Model 3: BE as an antecedent of CE (full mediating effects of CE)

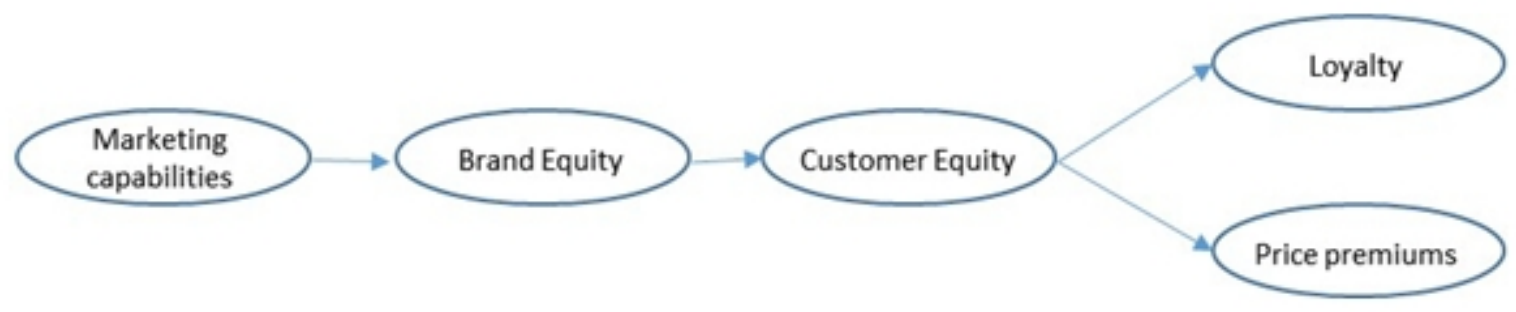

(d) Model 4: BE as an antecedent of CE (partial mediating effects of BE)

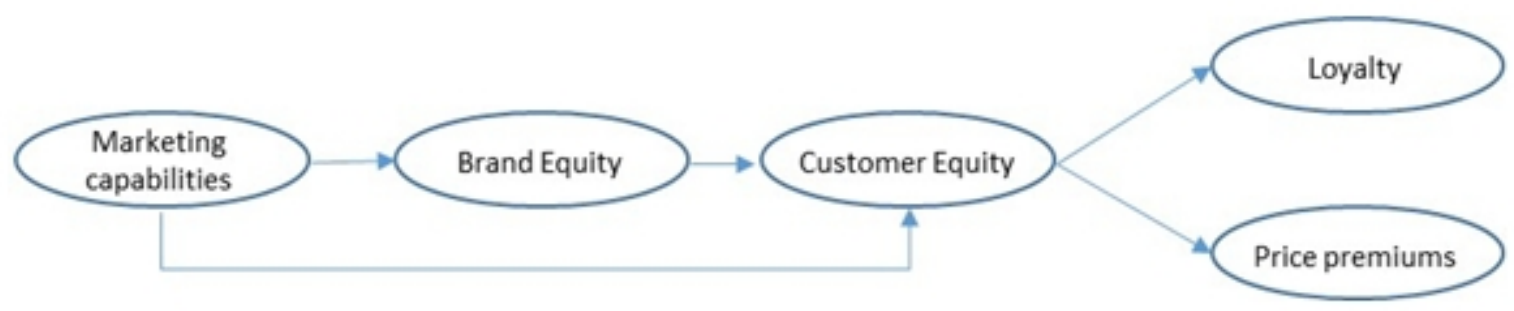

Figure 1. Research Models

Our third model proposes that BE is an antecedent of CE (Rust, Lemon et al., 2004). In this model we assume a full mediation of $\mathrm{CE}$ on the relationship between BE and loyalty and price premiums (Figure 1c). We also propose a fourth model in which $\mathrm{BE}$ is also an antecedent of CE (Figure 1d). Nevertheless, this model also allows marketing capabilities influencing directly CE formation, following Stahl et al. (2012). Both models are compatible with previous studies 
- that support that that marketing capabilities increase customer equity (that indeed omit the full or partial mediation of $\mathrm{BE}$ in this effect);

- and that indicate that BE produces loyalty and allows charging price premiums (despite not taking into account the mediating effect of $\mathrm{CE}$ on the relationship between $\mathrm{BE}$ and these competitive advantages).

\section{Method}

To test our four research models we employ Structural Equation Modelling. This tool can simultaneously estimate all the relationships included in complex models in which constructs are interrelated. In order to measure the variables of our model, we collected data from a survey of marketing managers working for service companies in Spain. Hence, our results are grounded on managerial practice. Managerial samples have a long tradition in management research (e.g. Greenley, 1998; Jantan, Honeycutt, Thelen \& Attia, 2004; Narasimhan, 1990; Pehrsson, 2006) and usually allow reaching similar results than other sources of data (Venkatraman \& Ramanujam, 1987; Reinartz, Krafft \& Hoyer, 2004).

A market research institute carried out the fieldwork via telephone surveys, using the CATI system, in November 2011. The sample (201 managers) was randomly taken from the 5,745 service companies registered in the database SABI (which contains the financial records of more than one million companies operating in Spain), ensuring an acceptable representativeness of the population. The sample proceeds from the following service industries: accommodation and food service activities; administrative and support service activities; arts, entertainment and recreation; education; financial and insurance activities; information and communication; professional, scientific and technical activities; real estate activities; retail trade, except of motor vehicles and motorcycles; supplies, sewerage, waste management and remediation activities; transportation and storage; and other services.

The latent variables used in the study were measured using scales validated by previous research (see Table 1). Marketing capabilities and BE were measured using primary Likert-type scales. CE indicators were measured using typified numerical scales as described in Table 1. The competitive advantages were assessed through price premium (Porter 1980; Prajogo, 2007; Winrow \& Johnson, 2010) and customer loyalty (Nurittamont \& Ussahawanitchakit, 2008; Aaker, 2012). For the former we used a seven-point scale of prices relative to the competition ("In relation with the competition, the prices of 
the services provided by your brands are: Over 20\% lower; Between 11\% and 20\% lower; Up to $10 \%$ lower; Similar; Up to 10\% higher; Between 11\% and 20\% higher; Over 20\% higher"). For customer loyalty, we devised a weighted average of five levels of loyalty multiplied by the estimated percentage of customers that fall within each level ("Distribute your current customer portfolio in accordance with the degree of loyalty shown towards your company when they have to buy a service in this category: between $90 \%$ and $100 \%$ of their purchases; between $70 \%$ and $89 \%$; between $50 \%$ and $69 \%$; between $30 \%$ and $49 \%$; less than $30 \%$ of the times" ${ }^{\circ}$ ).

\section{Analysis and results}

We applied a structural equations model estimated by maximum likelihood using the SPSS Amos 19 software program. As in any structural equations model, the analysis was implemented in two phases. First, we evaluated the psychometric properties of the measurement scales proposed for the latent variables of the model using both exploratory and confirmatory analysis techniques. Next, we assessed the goodness-of-fit of our models, which is particularly relevant for model comparisons, and evaluated their estimates.

\subsection{Validation of scales}

We initially applied an exploratory factor analysis and a reliability analysis to the items that define the scales of the latent variables of our model. After this initial filter, we dropped to two items from the original scale of marketing capabilities, due to incorrectly loadings in other variable. Hence, the marketing capabilities scale maintained eleven out of thirteen indicators. For the remaining variables, $\mathrm{BE}$ and $\mathrm{CE}$, every item loads on its corresponding latent variable. Subsequently, the analysis of the psychometric properties of our latent variables supports the validation of the scales finally used in this study (Table 1). Following Hair, Black, Babin, Anderson and Tatham (2006), the model presents a good global fit. Furthermore, all the indicators present standardized lambda coefficients that are both significant and greater than 0.5 (they vary between 0.62 and 0.88 ). Likewise, all the indicators have a clear relationship with each of the underlying factors they measure $\left(\mathrm{R}^{2}>0.3\right)$. Convergence validity of our model is adequate, according to the average variance extracted (AVE) of our latent variables. Similarly, the composite reliability values for the latent variables in the model exceed the critical value 
of 0.7 (Nunnally, 1978; Norusis, 1993). Additionally, the t-values of each indicator show that they are significant (Fornell \& Larcker, 1981).

With regard to discriminant validity, none of the confidence intervals of the estimated correlation between every pair of constructs contains 1 . Secondly, we tested a restricted model whose correlations estimates between latent variables are constrained to one towards our (unrestricted) model. The restricted model showed a significantly worse overall fit $\chi^{2}=141.84 ; \Delta \chi^{2}=5.41$. Finally, the square root of the AVE of each latent variable is higher than the correlations of that variable with any other construct (Table 2). All together, these tests support the discriminant validity of the latent variables of our study.

To check for potential common method bias, we applied Harman's single-factor test with a confirmatory factor analysis (e.g., Podsakoff, Mackenzie, Jeong-Yeon Lee \& Podsakoff, 2003). This test incorporates a single latent common factor in the model under study; subsequently it evaluates whether this factor can explain the majority of the model variance using a chi-square difference test. In our case, we implemented the test with regard to our basic measurement model with the three factors. The chisquare value of the single-factor model was 175.67 (d.f.=94), significantly worse than our basic measurement model with the three factors: $\Delta \chi^{2}=39.23, \Delta$ d.f. $=1 \mathrm{p}<0.001$. This provides evidences that the measurement model of our study is robust to common method bias.

\subsection{Model comparison}

Table 3 shows the goodness-of-fit indexes of estimation of models 1 to 4 . According to these indexes, models 1, 2 and 4 have an acceptable goodness-of-fit. Models 1 and 2 have better goodness-of-fit that models 3 and 4. In other words, the models that follow the perspective of Leone et al. (2006) have a higher goodness-of-fit that the models that reflect the point of view of Rust, Lemon et al. (2004). Consequently, our subsequent analyses are focused on models 1 and 2. 


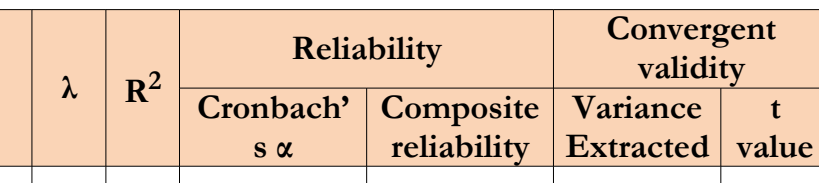

\section{Marketing Capabilities}

Assess your marketing capabilities relative to your principal competitors in the following areas. To do so use a scale of -5 to +5 , where $-5=$ "a great deal worse than your competitors", $0=$ "the same as your competitors" and $5=$ "a great deal better than your competitors" (Adapted from Morgan et al. (2009)):

Establishing a dialogue with the target audience.

Developing an initial test of the company's services by the target audience.

Satisfying the long-term needs of the target audience.

Maintaining loyalty among the attractive customers.

Strengthening the relations with the attractive customers.

Maintaining a positive relationship with ex-customers.

Establishing desirable brand associations in the mind of the consumer.

Maintaining a more positive brand image that that of your competitors.

Maintaining high levels of brand recognition within the market.

Making the most of brand equity to extend your brands.

Monitoring your brand image and recognition among your target audience.

Brand Equity

Likert scale (0-10), extracted from Keller (2001)

In your market, your brands are very well known.

Among your customers, the image of your brands is very good.

Among your customers, the perceived quality of your brands is very good.

\section{Customer Equity}

With respect to the customer base of the market in which you operate (the variables have been typified in a (0-10) scale to make them comparable to other scales in our questionnaire. Both variables are $\mathrm{CE}$ calculation components, e.g.: Berger and Nasr (1998), Gupta and Lehmann (2003), Gupta et al. (2004), Rust, Lemon et al. (2004), Rust, Ambler et al. (2004), Fader et al. (2005a, 2005b):

What is the average retention rate of your company's customers?

What is the average annual income obtained in your company?

GFI (goodness of fit index): .913; NFI (Normed fit index): .927; CFI (Comparative fit index):.975; RMSEA (root mean square error of approximation): .051; $\mathrm{S}-\mathrm{B} \chi^{2}=136.43$ (d.f. 93, $\left.\mathrm{p}=0.002\right) ; \chi^{2} /$ d.f. $=1.46$

Table 1. Reliability and Convergent Validity of Model Variables

\begin{tabular}{|c|c|c|c|c|c|}
\hline Latent variables & Mean & Standard Error & (1) & $(2)$ & (3) \\
\hline Marketing capabilities (1) & 7.82 & 1.29 & 0.75 & & \\
\hline Brand equity (2) & 7.67 & 1.19 & 0.52 & 0.80 & \\
\hline Customer equity (3) & 2.87 & 1.88 & 0.30 & 0.41 & 0.79 \\
\hline
\end{tabular}

Figures in the principal diagonal (in bold) correspond to the square root of the AVE of each latent variable; figures below the principal diagonal are the correlations between constructs.

Table 2. Descriptive Estimates of Latent Variables 


\begin{tabular}{|l|r|r|r|r|r|}
\cline { 2 - 6 } \multicolumn{1}{c|}{} & Model 1 & Model 2 & Model 3 & Model 4 & Model 2 (restricted) \\
\hline$\chi^{\mathbf{2}}$ & 169.63 & 169.28 & 265.70 & 183.34 & 170.91 \\
\hline d.f. & 125 & 123 & 126 & 125 & 125 \\
\hline$\chi^{\mathbf{2}} /$ d.f. & 1.36 & 1.38 & 2.10 & 1.47 & 1.37 \\
\hline $\mathbf{p}$ & 0.005 & 0.004 & 0.000 & 0.001 & 0.004 \\
\hline GFI & 0.90 & 0.90 & 0.86 & 0.90 & 0.90 \\
\hline CFI & 0.97 & 0.97 & 0.92 & 0.97 & 0.97 \\
\hline NFI & 0.91 & 0.91 & 0.87 & 0.90 & 0.91 \\
\hline RMSEA & 0.044 & 0.045 & 0.078 & 0.051 & 0.045 \\
\hline D $\chi^{2}$ (p-values) & $0.35(0.55)$ & - & $96.42(<0.01)$ & $14.06(<0.01)$ & $1.63(0.20)$ \\
\hline
\end{tabular}

Table 3. Goodness of Fit of the Four Research Models

Figure 2 shows the estimation results for models 1 and 2. Model 1 proposes that marketing capabilities build an overall marketing asset that is positively related with loyalty and customer willingness to pay price premiums. All the paths in model 1 are significant. Model 2 proposes that marketing capabilities build $\mathrm{BE}$ and $\mathrm{CE}$ and that both assets positively influence loyalty and customer willingness to pay price premiums. However, in this model our results indicate that BE does not affect customer loyalty and that $\mathrm{CE}$ has no impact on price premiums. Given these results, we have estimated a restricted version of model 2, where the non-significant coefficients are set to zero. Next, we have compared it to the "full" version of model 2. The difference in the fit of these two versions of model 2 is not significant $\left(\chi^{2}\right.$ test; Table 3). Moreover, the values of the restricted for the RMSEA, GFI, NFI and CFI are virtually identical to those of the original model. Thus, we present model 1 as-is in Figure 2 but, for parsimony, our subsequent analyses of model 2 (including Figure 2) will make reference to its restricted version.

There is not a significant difference between the overall fit of the models 1 and 2 ( $\chi^{2}$ incremental test). Both models represent Leone et al. (2006) perspective. Models coefficients indicate that the accumulation of marketing assets favors gaining competitive advantages (and therefore improving corporate results). Particularly, model 1 shows that the effect of the marketing asset on price premiums is positive and significant (.36), while its impact on customer loyalty, although also positive and significant, is lower (.19). Furthermore, model 1 indicates that marketing capabilities influence price premiums and loyalty, mediated by the building of the marketing asset. The total effects of marketing capabilities on these two competitive advantages are .23 and .12, respectively. According to model 2, BE does not directly improve loyalty and CE does not have a significant direct influence on customer willingness to pay price premiums. More specifically, the effect of CE on average loyalty is .21 and the impact of BE on price premium is .29 . Hence the total effect of marketing capabilities on loyalty is .09 (mediated by CE building) and .017 on price premiums (mediated by BE building). 
Hence, our models support Leone et al. (2006) perspective. Marketing activities affect the elements that grow BE and CE. This provokes a significant degree of simultaneity and overlapping between both assets, against the antecedent-consequent (BE-CE) relationship proposed by Rust, Zeithaml et al. (2004). The results of our estimations of model 1 suggest that BE and CE are first order constructs that reflect a broader marketing asset construct. Consistently, our results regarding model 2 indicate that there is a positive and significant correlation of .31 between BE and CE. The sign and significance of the estimated coefficients in both models provide an extra evidence of Leone et al. (2006) perspective.

Model 1: One marketing asset

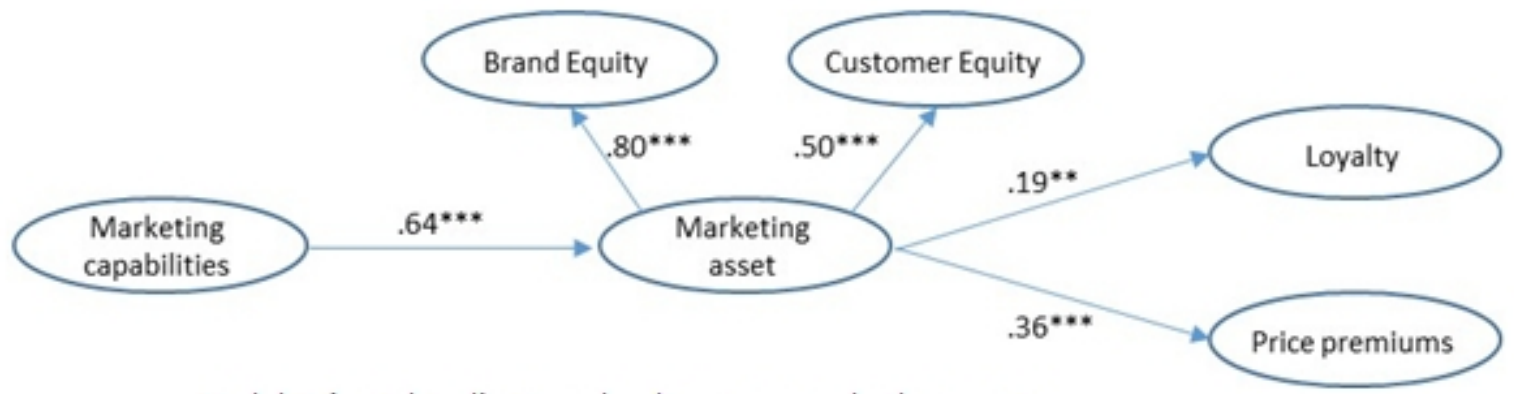

Model 2 (restricted): Two simultaneous marketing assets

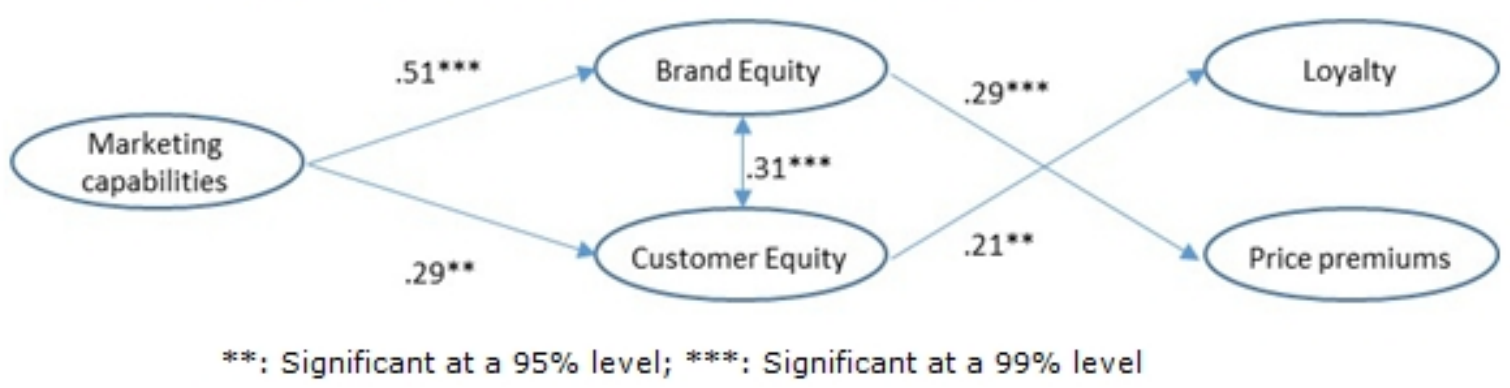

Figure 2. Estimation results

\section{Managerial implications}

In this study we compare two alternative approaches about the relationship between $\mathrm{BE}$ and $\mathrm{CE}$. On the one hand, Leone et al. (2006) approach suggests that marketing activities build both assets simultaneously, even to the extent of being different sides of the same coin (Ambler et al., 2002). On the other hand, Rust, Lemon et al. (2004) propose that BE is an antecedent of CE. We have estimated four alternative models that support these views, employing information provided by marketing managers. Our results support the approach of BE and CE simultaneity. The two models that we 
propose supporting this view have a higher goodness of fit that the other models that support that BE is an antecedent of CE. The goodness of fit of the former models is indeed quite similar, thus impeding to establish the superiority of one of them. This similar performance recommends caution when interpreting their results and analyzing their managerial implications.

Research model 1 proposes that BE and CE are two indicators of a broader marketing asset. Research model 2 separates BE and CE, but admits that both assets are highly correlated. Consistent with research model 1 , the results of research model 2 confirm this significant correlation, which is .31 in our study. With regard to the impact of BE and CE on customers' loyalty and their willingness to pay premiums prices, the models offer different insights. Our first model indicates that the marketing asset has a positive influence on both loyalty and price premiums. Nevertheless, when separating BE and $\mathrm{CE}, \mathrm{BE}$ only influences directly price premiums, while CE only has a direct influence on loyalty (.05 of confidence level). A potential explanation for this apparent divergence of results might be the existence of synergies between $\mathrm{BE}$ and $\mathrm{CE}$. When separating $\mathrm{BE}$ and $\mathrm{CE}$, their impact on competitive advantages appears more attenuated than when incorporating them in a model through a broader marketing asset. We observed differences between models 1 and 2 regarding the magnitude of the total effects of marketing capabilities on loyalty and price premiums (.03 and .06, respectively). Model 1 indicates that these effects are .12 and .23 , respectively, while in model 2 these are .09 and .17 . The results of model 2 indicate that $\mathrm{BE}$ and $\mathrm{CE}$ are correlated. Consequently, $\mathrm{BE}$ also indirectly influences average loyalty via CE. Similarly, CE has an indirect impact on price premiums. Hence, the indirect effect of BE on loyalty is .065 , while the indirect effect of CE on price premiums is .09 .

Our findings recommend paying attention to the coincidences and the differences between brands and customers management. Otherwise, resource allocation in marketing activities can be inefficient. In this regard, Ambler et al. (2002) indicate that brands and customers create value for the company by distinct and overlapping mechanisms. Acquiring new customers for current offerings, cross-buying from current customers, the ability to charge price premiums and reducing marketing costs are the common mechanisms that both brand and customer management can employ to provide value to companies. Extending into new areas with news customers and increasing purchases of current offerings by existing customers are mechanisms that correspond exclusively to brand and customer management, respectively. Although based on previous research, up to our knowledge this division of BE, CE and BE-CE mechanisms is not supported empirically yet in a study that jointly incorporates both assets. For instance, our research model 2 attributes the ability to charge price premiums basically to brand 
management, in contrast to Ambler and colleagues indications. Thus, our results recommend being cautious with their division of brand and customer management areas.

In any case, it is clear that brand and customer management cannot be separated. The managers in our sample indicate that $\mathrm{BE}$ and $\mathrm{CE}$ are built simultaneously, regardless they are the different indicators of a broader marketing construct or two different (but correlated) assets. Creating a solid base of marketing capabilities leads to gaining competitive advantages via these marketing assets. Both BE and CE are necessary to generate value for companies, given that they allow creating loyal customers who are willing to pay higher prices for firm products. Combining these two competitive advantages allows obtaining profits both in the short and in the long term. But how to integrate brand and customer management? Leone et al. (2006) recommend conceiving brand and customer management as a matrix where company brands are rows and customers (or segments) are the columns, thus taking into account both the rows and columns in order to arrive to optimal product solutions. However, implementing this recommendation can be quite challenging in practice.

Managing brands and customers portfolios together implies somehow moving to a management of brand-customer portfolios. The idea of brand-customer portfolios is appealing, but putting it in practice is only straightforward if there are not overlaps between the brands and the customers of the brand-customer portfolios identified by companies. In the simplest case, each brand of the company targets a single segment. Nevertheless, this is situation does not usually occur in practice.

(a) No overlapping brand-customer portfolios

\begin{tabular}{|c|c|c|c|c|c|}
\hline & Brand 1 & Brand 2 & Brand 3 & Brand 4 & Brand 5 \\
\hline Segment A & $\mathrm{X}$ & $\mathrm{X}$ & $\mathrm{X}$ & & \\
\hline Segment B & & & & $\mathrm{X}$ & \\
\hline Segmento C & & & & $\mathrm{X}$ & \\
\hline Segmento D & & & & & $\mathrm{X}$ \\
\hline
\end{tabular}

(b) Overlapping brand-customer portfolios

\begin{tabular}{|l|l|l|l|l|l|}
\hline & Brand 1 & Brand 2 & Brand 3 & Brand 4 & Brand 5 \\
\hline Segmento A & $\mathrm{X}$ & $\mathrm{X}$ & & & \\
\hline Segmento B & & $\mathrm{X}$ & $\mathrm{X}$ & & \\
\hline Segmento C & & & $\mathrm{X}$ & & \\
\hline Segmento D & & & $\mathrm{x}$ & $\mathrm{x}$ & $\mathrm{X}$ \\
\hline
\end{tabular}

Figure 3. Brand-customer portfolios 
Figure 3 illustrates two situations in which this condition does not hold, for a hypothetical firm selling five brands to four customer segments. Figure $3 \mathrm{a}$ shows a business setting where one segment purchases three company brands (segment A, brands 1,2 and 3), two segments are served by the same brand (segments B and C, brand 4) and one segment acquires only one brand (segment D, brand 5). This business setting is not problematic for adopting a brand-customer portfolio approach, as there are not overlaps between brands and customers. Here, the most natural solution is dividing the brandcustomer matrix in three brand-customer portfolios: a multi-brand portfolio, a multi-segment portfolio and a single brand-customer portfolio, corresponding to the three aforementioned combinations of brands and customers. All the three portfolios require an adequate management of customer acquisition and retention, together with brand or brands with a high awareness and an appropriate image. Additionally, for the first portfolio, promoting cross-selling can be key to improve profitability. Similarly, the second portfolio requires an appropriate policy to increase up-selling and customer referrals, as well as a precise segmentation to achieve high retention rates in each segment.

Figure $3 \mathrm{~b}$ shows a business setting where the separation of brands and customers in independent brand-customer portfolios is not possible. In effect, every brand-customer combination in Figure $3 \mathrm{~b}$ connects with another brand or customer segment. In this situation, companies might be forced to organize their business around brands or customers, and not around brand-customer portfolios, in order to manage efficiently their business.

Finally, our results have implications for firm valuation processes. An accurate firm valuation requires carefully measuring the company' intangible assets and incorporating them in firm value. According to our results, $\mathrm{BE}$ and $\mathrm{CE}$ could be to a high extent the same asset. Experts involved in firm valuation need to take into account this, in order to avoid oversizing value. In this regard, quantifying the overlap between $\mathrm{BE}$ and $\mathrm{CE}$ is key for achieving an adequate valuation. This is indeed a challenging task. In an exploratory study, Romero and Yagüe (2015) show that this overlap varies across industries. In effect, the relative importance of BE and CE for a company depends on industry factors (Bick, 2009), among others. Depending on data availability, experts involved in firm valuation could depart from measuring one asset and quantify the non-coinciding part provided by the other asset. For example, in the case of companies with proper databases to forecast customers' retention and margins, experts could firstly calculate the CE provided by their customer base using well-knows methods (e.g.: Fader et al., 2005a, 2005b). Subsequently, they would need to value the impact of company brands that does not spill over customers (for example: channel relationships, attraction of higher quality employees; Leone et al., 2006). In contrast, in the case of companies where this information is not available, experts could firstly 
apply BE measurement methods (Yoo \& Donthu, 2001; Christodoulides \& de Chernatony, 2010) and, subsequently value the profits derived from customer management that not spill directly over customers' purchases. According to Kumar et al. (2010) these profits include customer referral value (the value provided by customers by recommending company brands in exchange of some incentives) and customer knowledge value (the value provided by customers by sharing their knowledge about brands to companies, thus facilitating product improvement, new product development, etc.).

\section{Conclusions and future lines of research}

This work provides new evidence regarding the relationship between BE and CE. We have studied this relationship within the resource-based view framework. To do so, we test two alternative approaches about the link between $\mathrm{BE}$ and $\mathrm{CE}$. The first approach suggest that both assets are built simultaneously, while the second one suggests that BE is an antecedent of CE. Our results support that $\mathrm{BE}$ and $\mathrm{CE}$ are built simultaneously. Moreover, they could be two indicators of a broader marketing asset. Our results also indicate that $\mathrm{BE}$ allows companies to charge price premiums and that $\mathrm{CE}$ is positively related with loyalty, in contrast to previous research that attributes these competitive advantages to both BE and CE. From a theoretical point of view our results recommend devoting efforts to integrate brand and customer management research. For instance, the role of brands on customer referrals or on enhancing customers sharing their knowledge about the product with companies could be fruitful research directions. Similarly, studying the role of customer management on brand image, brand awareness, etc. would help academics and practitioners obtaining a deeper comprehension regarding marketing profitability formation. From a managerial perspective, our results point out the relevance of clarifying how brands and customers contribute to value creation. Our findings also recommend moving from a brand portfolio or customer portfolio management to a brand-customer portfolio management when possible. Finally, our results indicate that the simultaneity of $\mathrm{BE}$ and $\mathrm{CE}$ must be taken into account when performing firm valuation processes.

To sum up, the conclusions of our study have implications both for researchers in the area of $\mathrm{BE}$ and $\mathrm{CE}$ and marketing profitability, and for practitioners that need somehow to balance the management of their brands and customers or to assess correctly the value of firms. Nevertheless, this work is not free of limitations. First, some managers in our sample might inaccurately assess customer behaviors, perceptions, etc., and their performance in their markets. The employment of other measurement procedures would increase the external validity of our research. In this regard, the difficulties we had in 
finding a scale for measuring $\mathrm{CE}$ that reflects the main financial components of the concept deserves special attention: the scale used consists of two indicators whose measurement is different from that of the rest of the variables; this fact hinders a direct comparison of the average $\mathrm{BE}$ and $\mathrm{CE}$ levels achieved by the companies in our sample. Moreover, this may affect the magnitudes of some of the coefficients estimates. Secondly, the fact that our analysis was carried out on different service sectors prevents us from knowing the stability of the models if they were to be applied to other industries, as suggested by Bick (2009). Enriching our sample could help to assess a potential generalization of our results and to detect whether the effects of $\mathrm{BE}$ and $\mathrm{CE}$ upon competitive advantages are similar or different according to the type of industry. Finally, we have focused on two main outputs provided by brand and customer management. However, other outputs could have been included in our work, thus expanding the scope and measurement of competitive advantages that affect economic results in terms of profit margins and sales growth.

\section{Acknowledgements}

Funded by Ministerio de Economía y Competitividad (ECO2012-31517)

\section{References}

Aaker, D.A. (1991). Managing Brand Equity. New York: Free Press.

Aaker, D.A. (1996). Building Strong Brands. New York: Free Press.

Aaker, D.A. (2012). Win the Brand Relevance Battle and then Build Competitor Barriers. California Management Review, 54(2), 43-57. http://dx.doi.org/10.1525/cmr.2012.54.2.43

Ailawadi, K.L., Lehmann, D.R., \& Neslin, S.A. (2003). Revenue Premium as an Outcome Measure of Brand Equity. Journal of Marketing, 67(4), 1-17. http://dx.doi.org/10.1509/jmkg.67.4.1.18688

Allaway, A.W., Huddleston, P., Whipple, J. \& Ellinger, A.E. (2011). Customer-based Brand Equity, Equity Drivers, and Customer Loyalty in the Supermarket Industry. Journal of Product and Brand Management, 20(3), 190-204. http://dx.doi.org/10.1108/10610421111134923

Allenby, G.M., Leone, R.P., \& Jen, L. (1999). A Dynamic Model of Purchase Timing with Application to Direct Marketing. Journal of the American Statistical Association, 94(446), 365-374. http://dx.doi.org/10.1080/01621459.1999.10474127 
Ambler, T. (2003). Marketing: The Trouble with Finance. Business Strategy Review, 14(3), 54-62. http://dx.doi.org/10.1111/1467-8616.00274

Ambler, T., Bhattacharya, C.B., Edell, J., Keller, K.L., Lemon, K.N., \& Mittal, V. (2002). Relating Brand and Customer Perspectives on Marketing Management. Journal of Service Research, 5(1), 13-25. http://dx.doi.org/10.1177/1094670502005001003

Bauer, H.H., \& Hammerschmidt, M. (2005). Customer-based Corporate Valuation. Management Decision, 43(3), 331-348. http://dx.doi.org/10.1108/00251740510589733

Berger, P.D., \& Nasr, N.I. (1998). Customer Lifetime Value: Marketing Models and Applications. Journal of Interactive Marketing, 12(1), 17-30. http://dx.doi.org/10.1002/(SICI)1520-6653(199824)12:1<17::AIDDIR3>3.0.CO;2-K

Bick, G.N.C. (2009). Increasing Shareholder Value through Building Customer and Brand Equity. Journal of Marketing Management, 25(1), 117-141. http://dx.doi.org/10.1362/026725709X410061

Chen, C., \& Myagmarsuren, O. (2011). Brand equity, Relationship Quality, Relationship Value, and Customer Loyalty: Evidence from the telecommunications services. Total Quality Management and Business Excellence, 22(9), 957-974. http://dx.doi.org/10.1080/14783363.2011.593872

Chernatony, L., Mcdonald, M., \& Wallace, E. (2010). Creating Powerful Brands. UK: HB (Elsevier).

Christodoulides, G., \& De Chernatony, L. (2010). Consumer-based Brand Equity Conceptualisation and Measurement. International Journal of Market Research, 52(1), 43-66. http://dx.doi.org/10.2501/S1470785310201053

Del Río, A., Vázquez, R., \& Iglesias, V. (2001). The Effects of Brand Associations on Consumer Response. Journal of Consumer Marketing, 18(5), 410-425. http://dx.doi.org/10.1108/07363760110398808

Den Hertog, P., Van Der Aa, W., \& De Jong, M.W. (2010). Capabilities for Managing Service Innovation: towards a Conceptual Framework. Journal of Service Management, 21(4), 490-514. http://dx.doi.org/10.1108/09564231011066123

Fader, P.S., Hardie, B.G.S., \& Lee, K.L. (2005a). "Counting your Customers" the Easy Way: An Alternative to the Pareto/NBD Model. Marketing Science, 24(2), 275-284. http://dx.doi.org/10.1287/mksc.1040.0098

Fader, P.S., Hardie, B.G.S., \& Lee, K.L. (2005b). RFM and CLV: Using Iso-value Curves for Customer Base Analysis. Journal of Marketing Research, 42(4), 415-430. http://dx.doi.org/10.1509/jmkr.2005.42.4.415 
Faircloth, J.B., Capella, L.M., \& Alford, B.L. (2001). The Effect of Brand Attitude and Brand Image on Brand Equity. Journal of Marketing Theory and Practice, 9(3), 61-75. http:/ /dx.doi.org/10.1080/10696679.2001.11501897

Fornell, C., \& Larcker, D.F. (1981). Evaluating Structural Equation Models with Unobservable Variables and Measurement Error. Journal of Marketing Research, 18(1), 39-50. http://dx.doi.org/10.2307/3151312

Geigenmüller, A., \& Bettis-Outland, H. (2012). Brand Equity in B2B Services and Consequences for the Trade Show Industry. Journal of Business and Industrial Marketing, 27(6), 428-435. http://dx.doi.org/10.1108/08858621211251433

Greenley, G.E. (1988). Managerial Perceptions of Marketing Planning. Journal of Management Studies, 25(6), 575-601. http://dx.doi.org/10.1111/j.1467-6486.1988.tb00048.x

Gupta, S., \& Lehmann, D.R. (2003). Customers as Assets. Journal of Interactive Marketing, 17(1), 9-24. http://dx.doi.org/10.1002/dir.10045

Gupta, S., Lehmann, D.R., \& Stuart, J.A. (2004). Valuing Customers. Journal of Marketing Research, 41(1), 7-18. http://dx.doi.org/10.1509/jmkr.41.1.7.25084

Hair, J.F., Black, B., Babin, B., Anderson, R.E., \& Tatham, R.L. (2006). Multivariate Data Analysis (6th ed.). Upper Saddle River (NJ): Prentice Hall.

Hao, Z., Ko, E., \& Taylor, C.R. (2010). Advertising Appeals Strategy: Moderating Effect on the Relationship between Innovation and Customer Equity. Advances in International Marketing, 9(21), 111-136.

Hogan, J.E., Lemon, K.N., \& Rust, R.T. (2002). Customer Equity Management: Charting New Directions for the Future of Marketing. Journal of Service Research, 5(1), 4-12. http://dx.doi.org/10.1177/1094670502005001002

Holehonnur, A., Raymond, M.A., Hopkins, C.D., \& Fine, A.C. (2009). Examining the Customer Equity Framework from a Consumer Perspective. Journal of Brand Management, 17(3), 165-180. http://dx.doi.org/10.1057/bm.2009.21

Hulland, J., Wade, M.R., \& Antia, K.D. (2007). The Impact of Capabilities and Prior Investments on Online Channel Commitment and Performance. Journal of Management Information Systems, 23(4), 109-142. http://dx.doi.org/10.2753/MIS0742-1222230406 
Jantan, M.A., Honeycutt, E.D., Thelen, S.T., \& Attia, A.M. (2004). Managerial perceptions of sales training and performance. Industrial Marketing Management, 33(7), 667-673. http://dx.doi.org/10.1016/j.indmarman.2003.09.003

Jobber, D., \& Shipley, D. (2012). Marketing-orientated Pricing: Understanding and Applying Factors that Discriminate between Successful High and Low Price Strategies. European Journal of Marketing, 46(11/12), 1647-1670. http://dx.doi.org/10.1108/03090561211260022

Johansson, J.K., Dimofte, C.V., \& Mazvancheryl, S.K. (2012). The Performance of Global Brands in the 2008 Financial Crisis: a Test of Two Brand Value Measures. International Journal of Research in Marketing, 29(3), 235-245. http://dx.doi.org/10.1016/j.ijresmar.2012.01.002

Jones, R. (2005). Finding Sources of Brand Value: Developing a Stakeholder Model of Brand Equity. Journal of Brand Management, 13(10), 10-32. http://dx.doi.org/10.1057/palgrave.bm.2540243

Juntunen, M., Juntunen, J., \& Juga, J. (2011). Corporate Brand Equity and Loyalty in B2B Markets: A Study among Logistics Service Purchasers. Journal of Brand Management, 18(4/5), 300-311. http://dx.doi.org/10.1057/bm.2010.43

Keller, K.L. (1993). Conceptualizing, Measuring, Managing Customer-based Brand Equity. Journal of Marketing, 57(1), 1-22. http://dx.doi.org/10.2307/1252054

Keller, K.L. (2001). Building Customer-based Brand Equity: a Blueprint for Creating Strong Brands (Working Papers Series, 01-107): Cambridge, MA: Marketing Science Institute.

Keller, K.L. (2008). Strategic Brand Management: Building, Measuring, and Managing Brand Equity (3rd ed.). Upper Saddle River (NJ): Prentice Hall.

Kerin, R.A., \& Sethuraman, R. (1998). Exploring the Brand Value-Shareholder Value Nexus for Consumer Goods Companies. Journal of the Academy of Marketing Science, 26(4), 260-273. http://dx.doi.org/10.1177/0092070398264001

Kim, H.-B., \& Kim Woo, G. (2005). The Relationship between Brand Equity and Firms' Performance in Luxury Hotels and Chain Restaurants. Tourism Management, 26(4), 549-560. http://dx.doi.org/10.1016/j.tourman.2004.03.010

Kim, H.-B., Kim Woo, G., \& An Jeong, A. (2003). The Effect of Consumer-based Brand Equity on Firms' Financial Performance. Journal of Consumer Marketing, 20(4), 335-351. 
Kumar, V., Lemon, K.N., \& Parasuraman, A. (2006). Managing Customers for Value: An Overview and Research Agenda. Journal of Service Research, 9(2), 87-94. http://dx.doi.org/10.1177/1094670506293558

Kumar, V., Aksoy, L., Donkers, B., Venkatesan, R., Wiesel, T., \& Tillmanns, S. (2010). Undervalued or Overvalued Customers: Capturing Total Customer Engagement Value. Journal of Service Research, 13(3), 297-310. http://dx.doi.org/10.1177/1094670510375602

Lassar, W., Mittal, B., \& Sharma, A. (1995). Measuring Customer-based Brand Equity. Journal of Consumer Marketing, 12(4), 11-19. http://dx.doi.org/10.1108/07363769510095270

Leone, R.P., Rao, V.R., Keller, K.L., Luo, A.M., Mcalister, L., \& Srivastava, R.K. (2006). Linking Brand Equity to Customer Equity. Journal of Service Research, 9(2), 125-138. http://dx.doi.org/10.1177/1094670506293563

Luo, A., Lehmann, D.R., \& Neslin, S.A. (2015). Co-managing Brand Equity and Customer Equity. In V. Kumar \& Denish Shah (Eds), Handbook of Research on Customer Equity in Marketing (pp. 363-381). Cheltenham, UK: Edward Elgar Publishing Ltd. http://dx.doi.org/10.4337/9781781004982.00024

Morgan, N.A., Slotegraaf, R.J., \& Vorhies, D.W. (2009). Linking Marketing Capabilities with Profit Growth. International Journal of Research in Marketing, 26(4), 284-293. http://dx.doi.org/10.1016/j.ijresmar.2009.06.005

Morgan, N.A., Vorhies, D.W., \& Mason, C.H. (2009). Market Orientation, Marketing Capabilities, and Firm Performance. Strategic Management Journal, 30(8), 909-920. http://dx.doi.org/10.1002/smj.764

Narasimhan, C. (1990). Managerial Perspectives on Trade and Consumer Promotions. Marketing Letters, 1(3), 239-251. http://dx.doi.org/10.1007/BF00640801

Netemeyer, R.G., Krishnan, B., Pullig, C., Wang, G., Yagci, M., Dean, D., Ricks, J., \& Wirth, F. (2004). Developing and Validating Measures of Facets of Customer-based Brand Equity. Journal of Business Research, 57(2), 209-224. http://dx.doi.org/10.1016/S0148-2963(01)00303-4

Norusis, M.J. (1993). SPSS. Statistical Data Analysis. Chicago: SPSS Inc.

Nunnally, J.C. (1978). Psychometric Theory (2nd ed.). New York: McGraw-Hill.

Nurittamont, W., \& Ussahawanitchakit, P. (2008). The Influences of Brand Equity in Competitive Advantage and Performance of Spa Business in Thailand. Journal of International Business Strategy, 8(2), $14-25$. 
Park, C.S., \& Srinivasan, V. (1994). A Survey-based Method for Measuring and Understanding Brand Equity and its Extendibility. Journal of Marketing Research, 31(2), 271-288.

http://dx.doi.org/10.2307/3152199

Pehrsson, A. (2006). Business Relatedness and Performance: a Study of Managerial Perceptions. Strategic Management Journal, 27(3), 265-282. http://dx.doi.org/10.1002/smj.516

Podsakoff, P.M., Mackenzie, S.B., Jeong-Yeon Lee, \& Podsakoff, N.P. (2003). Common Method Biases in Behavioral Research: A Critical Review of the Literature and Recommended Remedies. Journal of Applied Psychology, 88(5), 879-903. http://dx.doi.org/10.1037/0021-9010.88.5.879

Porter, M.E. (1980). Competitive Strategy: Techniques for Analyzing Industries and Competitors. New York: Free Press.

Porter, M.E. (1985). Competitive Advantage. Creating and Sustaining Superior Performance. New York: Free Press.

Porter, M.E. (1991). Towards a Dynamic Theory of Strategy. Strategic Management Journal, 12(4), 95-117. http://dx.doi.org/10.1002/smj.4250121008

Prajogo, D.I. (2007). The Relationship between Competitive Strategies and Product Quality. Industrial Management and Data Systems, 107(1), 69-83. http://dx.doi.org/10.1108/02635570710719061

Raggio, R.D., \& Leone, R.P. (2007). The Theoretical Separation of Brand Equity and Brand Value: Managerial Implications for Strategic Planning. Journal of Brand Management, 14(5), 380-395. http://dx.doi.org/10.1057/palgrave.bm.2550078

Ramaseshan, B., Rabbanee, F.K., \& Hui, L.T.H. (2013). Effects of Customer Equity Drivers on Customer Loyalty in B2B Context. Journal of Business and Industrial Marketing, 28(4), 335-346. http://dx.doi.org/10.1108/08858621311313929

Rao, A.R., \& Monroe, K.B. (1996). Causes and Consequences of Price Premiums. Journal of Business, 69(4), 511-535. http://dx.doi.org/10.1086/209703

Rao, V.R., Agarwal, M.K., \& Dahlhoff, D. (2004). How is Manifest Branding Strategy Related to Intangible Value of a Corporation?. Journal of Marketing, 68(4), 126-141. http://dx.doi.org/10.1509/jmkg.68.4.126.42735

Reinartz, W., Krafft, M., \& Hoyer, W.D. (2004). The Customer Relationship Management Process: Its Measurement and Impact on Performance. Journal of Marketing Research, 41(3), 293-305. http://dx.doi.org/10.1509/jmkr.41.3.293.35991 
Romero, J., \& Yagüe, M. (2015). Relating brand equity and customer equity An exploratory study. International journal of Market Research, 57(4), 631-651. http://dx.doi.org/10.2501/IJMR-2015-050

Rust, R.T., Ambler, T., Carpenter, G.S., Kumar, V., \& Srivastava, R.K. (2004). Measuring Marketing Productivity: Current Knowledge and Future Directions. Journal of Marketing, 68(4), 76-89. http://dx.doi.org/10.1509/jmkg.68.4.76.42721

Rust, R.T., Lemon, K.N., \& Zeithaml, V.A. (2004). Return on Marketing: Using Customer Equity to Focus Marketing Strategy. Journal of Marketing, 68(1), 109-127. http://dx.doi.org/10.1509/jmkg.68.1.109.24030

Rust, R.T., Zeithaml, V.A., \& Lemon, K.N. (2000). Driving Customer Equity: How Customer Lifetime Value is Reshaping Corporate Strategy. New York: Free Press.

Rust, R.T., Zeithaml, V.A., \& Lemon, K.N. (2004). Customer-centered Brand Management. Harvard Business Review, 82(9), 110-118.

Simon, C.J., \& Sullivan, M.W. (1993). The measurement and determinants of brand equity: A financial approach. Marketing Science, 12(1), 28-52. http://dx.doi.org/10.1287/mksc.12.1.28

Spyropoulou, S., Skarmeas, D., \& Katsikeas, C.S. (2011). An Examination of Branding Advantage in Export Ventures. European Journal of Marketing, 45(6), 910-935. http://dx.doi.org/10.1108/03090561111119967

Srivastava, R.K., Fahey, L., \& Christensen, H.K. (2001). The Resource-based View and Marketing: The Role of Market-based Assets in Gaining Competitive Advantage. Journal of Management, 27(6), 777-802. http://dx.doi.org/10.1177/014920630102700610

Srivastava, R.K., Shervani, T.A., \& Fahey, L. (1998). Market-based Assets and Shareholder Value: A Framework for Analysis. Journal of Marketing, 62(1), 2-18. http://dx.doi.org/10.2307/1251799

Srivastava, R.K., Shervani, T.A., \& Fahey, L. (1999). Marketing, Business Processes, and Shareholder value: An Organizationally Embedded View of Marketing Activities and the Discipline of Marketing. Journal of Marketing, 63(4), 168-179. http://dx.doi.org/10.2307/1252110

Stahl, F., Heitmann, M., Lehmann, D.R., \& Neslin, S.A. (2012). The Impact of Brand Equity on Customer Acquisition, Retention, and Profit Margin. Journal of Marketing, 76(4), 44-63. http://dx.doi.org/10.1509/jm.10.0522

Taylor, S.A., Celuch, K., \& Goodwin, S. (2004). The Importance of Brand Equity to Customer Loyalty. Journal of Product \& Brand Management, 13(4), 217-227. http://dx.doi.org/10.1108/10610420410546934 
Taylor, S.A., Hunter, G.L., \& Lindberg, D.L. (2007). Understanding (Customer-based) Brand Equity in Financial Services. The Journal of Services Marketing, 21(4), 241-252. http://dx.doi.org/10.1108/08876040710758540

Teece, D.J., \& Pisano, G. (1994). The Dynamic Capabilities of Firms: An Introduction. Industrial and Corporate Change, 3(3), 537-556. http://dx.doi.org/10.1093/icc/3.3.537-a

Teece, D.J., Pisano, G., \& Shuen, A. (1997). Dynamic Capabilities and Strategic Management. Strategic Management Journal, 18(7), 509-533. http://dx.doi.org/10.1002/(SICI)1097-0266(199708)18:7<509::AIDSMJ882>3.0.CO;2-Z

Van Doorn, J., Lemon, K.N., Mittal, V., Nass, S., Pick, D., Pirner, P., \& Verhoef, P.C. (2010). Customer Engagement Behavior: Theoretical Foundations and Research Directions. Journal of Service Research, 13(3), 253-266. http://dx.doi.org/10.1177/1094670510375599

Venkatesan, R., \& Kumar, V. (2004). A Customer Lifetime Value Framework for Customer Selection and Resource Allocation Strategy. Journal of Marketing, 68(4), 106-125. http://dx.doi.org/10.1509/jmkg.68.4.106.42728

Venkatraman, N., \& Ramanujam, V. (1987). Measurement of Business Economic Performance: An Examination of Method Convergence. Journal of Management, 13(1), 109-122. http://dx.doi.org/10.1177/014920638701300109

Villanueva, J., \& Hanssens, D.M. (2007). Customer Equity: Measurement, Management and Research Opportunities. Foundations and Trends in Marketing, 1(1),1-95. http://dx.doi.org/10.1561/1700000002

Villanueva, J., Yoo, S., \& Hanssens, D.M. (2008). The Impact of Marketing-induced Versus Word-ofmouth Customer Acquisition on Customer Equity Growth. Journal of Marketing Research, 45(1), 48-59. http://dx.doi.org/10.1509/jmkr.45.1.48

Vorhies, D.W., \& Morgan, N.A. (2005). Benchmarking Marketing Capabilities for Sustainable Competitive Advantage. Journal of Marketing, 69(1), 80-94. http://dx.doi.org/10.1509/jmkg.69.1.80.55505

Wang, C., Hsu, L., \& Fang, S. (2009). Constructing a Relationship-based Brand Equity Model. Service Business, 3(3), 275-292. http://dx.doi.org/10.1007/s11628-008-0062-2

Wiesel, T., Skiera, B., \& Villanueva, J. (2008). Customer Equity: An Integral Part of Financial Reporting. Journal of Marketing, 72(2), 1-14. http://dx.doi.org/10.1509/jmkg.72.2.1

Winrow, B.P., \& Johnson, K. (2010). Minimum Price Maintenance Agreements and Premium Pricing Strategy. Journal of Legal, Ethical and Regulatory Issues, 13(1), 75-85. 
Yoo, B., \& Donthu, N. (2001). Developing and Validating a Multidimensional Consumer-based Brand

Equity Scale. Journal of Business Research, 52(1), 1-14. http://dx.doi.org/10.1016/S0148-2963(99)00098-3

Yoo, B., Donthu, N., \& Lee, S. (2000). An Examination of Selected Marketing Mix Elements and

Brand Equity. Journal of the Academy of Marketing Science, 28(2), 195-211.

http://dx.doi.org/10.1177/0092070300282002

Intangible Capital, 2016 (www.intangiblecapital.org)

Article's contents are provided on an Attribution-Non Commercial 3.0 Creative commons license. Readers are allowed to copy, distribute and communicate article's contents, provided the author's and Intangible Capital's names are included. It must not be used for commercial purposes. To see the complete license contents, please visit http://creativecommons.org/licenses/by-nc/3.0/. 